\title{
Microbial air contamination on the premises of the sewage treatment plant in Bydgoszcz (Poland) and antibiotic resistance of Staphylococcus spp.
}

\author{
Marta Małecka-Adamowicz*, Łukasz Kubera, Wojciech Donderski, Katarzyna Kolet \\ Kazimierz Wielki University in Bydgoszcz, Poland \\ Faculty of Natural Science, Institute of Experimental Biology, Department of Microbiology
}

*Corresponding author's e-mail: marmal@ukw.edu.pl

Keywords: bioaerosols, treatment plant, Antimicrobial resistance, air contamination.

\begin{abstract}
The study was aimed at evaluating microbial contamination on the premises of the sewage treatment plant by determining the concentrations of selected groups of airborne microorganisms. Another objective was to determine the antibiotic sensitivity patterns of isolated strains of staphylococci. The research was conducted in a seasonal cycle, by the impaction method using Merck MAS-100 air sampler. Samples were collected at six sites, each representing a different stage of sewage treatment. The susceptibility of isolated staphylococci was assessed with the disc-diffusion method, following the recommendations of the EUCAST. The results indicate that the microbial population in the air of the investigated area was dominated by mold fungi, whose highest average concentration was recorded at site IV located near the final clarifier $\left(7672 \mathrm{CFU} \cdot \mathrm{m}^{-3}\right)$. Heterotrophic bacteria and mannitol-positive staphylococci were the most numerous at locations where sewage undergoes primary treatment. In each subseuqent stage the number of microorganisms emitted into the air from the sewage was lower. Antibiograms show that more than 50\% of Staphylococcus spp. exhibited resistance to penicillin and $20 \%$ to rifampicin. In addition, $90 \%$ of the analyzed strains were sensitive to other antibiotics. The fungal community included the following genera: Cladosporium, Fusarium, Alternaria, Penicillium, Aspergillus, Aureobasidium, and Acremonium. The highest air contamination with all studied groups of microorganisms was recorded at the locations where mechanical sewage treatment was performed. During the subsequent stages lower numbers of heterotrophic bacteria were emitted into the air.
\end{abstract}

The air in the investigated sewage treatment plant did not contain multidrug-resistant staphylococci.

\section{Introduction}

The microbial world is a vast universe with innumerable species. Microorganisms have been found in caverns, deep seas, hot springs, and other places uninhabited by people.

They also populate indoor and outdoor environments in urban and rural areas (Barberan et.al. 2015).

Despite their unprecedented role in protecting the environment, sewage treatment plants are also sources of bioaerosol emission (Michałkiewicz et al. 2009, Filipkowska et al. 2009, Breza-Boruta 2010, Michałkiewicz et al. 2011). The level of pollution caused by these facilities depends on many factors including the composition of sewage, the concentration of microorganisms in sewage, the size and capacity of the facility, methods and equipment, and meteorological conditions (Breza-Boruta 2010). Harmful microorganisms are released from the equipment used in the plant hence prolonged exposure of staff to bioaresol emission in certain places can be dangerous (Michałkiewicz 2015). Numerous studies indicate that bioaerosol is detected in areas located up to $3 \mathrm{~km}$ from the plant (Michalak and Pawlas 2012), which means that bioaerosol emission from sewage into the air poses health hazard not only for the employees of the plant but also for the residents of the neighboring areas (Kołwzan et al. 2012). The most commonly reported problems include respiratory infections, digestive disorders, skin allergies and general symptoms, which can be caused by endotoxins and mycotoxins released by bacteria and fungi (Michalak and Pawlas 2012).

Bioaerosols formed during sewage treatment most commonly contain intestinal bacteria, bacteria of the genus Pseudomonas, yeasts and fungi, dermatophytes of the Trichophyton and Microsporum genera, protozoan cysts and worm eggs, enteroviruses, and retroviruses (Kołwzan et al. 2005). The bacterial community is dominated by staphylococci and streptococci (Łebkowska 2001), which indicates the presence of drug-resistant pathogens.

The rise of antibiotic resistance among pathogenic bacteria is observed with increasing frequency. This trend in bacterial evolution has a tremendous influence on human health and is therefore a priority challenge for modern medicine. 
A range of local and global factors affect the impact of municipal facilities (including sewage treatment plants) on the environment and human health. The regular monitoring of this kind of premises seems to be a necessary measure.

\section{Materials and Methods}

Microbial air quality was assessed on the premises of the sewage treatment plant located in north-east Bydgoszcz, Poland. Every day the plant receives up to $41,000 \mathrm{~m}^{3}$ of wastewater collected from the city areas spread on the left bank of the Brda River and from the neighboring municipalities i.e. Dobrcz, Osielsko and Dąbrowa Chełmińska. The facility has a modern sewage sludge incineration plant.

\section{Sampling sites and sampling}

The research was conducted in a seasonal cycle (spring, summer, autumn, winter), by the impaction method using Merck MAS-100 air sampler. Samples were collected at six sites, each representing a different stage of sewage treatment: Site I - near the bar screen, Site II - near the primary clarifier, Site III - between the aeration tanks and bioreactors, Site IV - near the final clarifier, Site V - near the effluent sampling chamber, Site VI - near the entrance to the plant.

The amount of 50-100 liters of air (depending on the expected contamination level) was filtered in the sampler's chamber containing a Petri dish filled with a suitable nutrient medium. The microorganisms from the air stream were sucked in by the air sampler and deposited on the surface of the medium. Sampling was always conducted in three parallel repeats. The air samples were transported to the laboratory, placed in a thermostat and incubated for a specific time at an appropriate temperature. Subsequently, the grown colonies were counted and their number was expressed as colony forming units per cubic meter of air $\left(\mathrm{CFU} \cdot \mathrm{m}^{-3}\right)$.

\section{Microbiological analysis}

The microbial analysis determined the following: 1) the total number of heterotrophic bacteria, 2) the number of mannitol-positive bacteria of the Staphylococcus genus and their resistance to antibiotics 3) the number and genera of mold fungi.

The total number of heterotrophic bacteria was determined using TSA agar medium. Bacteria were incubated at $37^{\circ} \mathrm{C}$ for 48 hours, then grown colonies were counted and their number was expressed as colony forming units per cubic meter of air $\left(\mathrm{CFU} \cdot \mathrm{m}^{-3}\right)$.

The presence of mannitol-positive staphylococci was detected using Chapman nutrient medium (Biocorp, Poland). Bacterial cultures were incubated at $37^{\circ} \mathrm{C}$ for 48 hours and then grown colonies were counted. A bright yellow zone around a colony indicated a positive result. In addition, taxonomic analysis of the strains was performed using BIOLOG fingerprinting method.

Antibiotic resistance of the identified staphylococcus strains was determined using the disc diffusion method. Paper discs containing antibiotics were placed on medium inoculated with randomly selected strains of mannitol-positive staphylococci. Eight different groups of antibiotics (penicillin, cefoxitin, gentamycin, erythromycin, tetracycline, levofloxacin, chloramphenicol and rifampicin) were used to assess the full spectrum of resistance of the strains (Table 1). After an 18-hour incubation at $37^{\circ} \mathrm{C}$ we measured zones of inhibited growth formed around the discs. The results were compared with the guidelines of the European Committee on Antimicrobial Susceptibility Testing (EUCAST 2015). Subsequently, the investigated strains were divided into three groups: susceptible, moderately susceptible and resistant to antibiotics.

The number of mold fungi was determined using Sabouraud's nutrient medium (Biocorp, Poland). After five days of incubation at $26^{\circ} \mathrm{C}$, grown colonies were counted and their number was expressed as colony forming units per cubic meter of air $\left(\mathrm{CFU} \cdot \mathrm{m}^{-3}\right)$. Mold fungi were identified on the basis of their macro- and microscopic features using the Samson et al. (2000) key.

The results were analyzed in STATISTICA 6.0. Statistical analysis was based on Kruskal-Wallis test (one-way ANOVA on ranks), which assesses statistically significant differences between groups of data.

\section{Results}

The results indicate that the population of microorganisms in the air of the investigated area was dominated by mold fungi (Table 2), whose highest average concentration $\left(7672 \mathrm{CFU} \cdot \mathrm{m}^{-3}\right)$ was recorded at sampling site IV located at the final clarifier. At the remaining sites their average concentration ranged from $1858 \mathrm{CFU} \cdot \mathrm{m}^{-3}$ to $2860 \mathrm{CFU} \cdot \mathrm{m}^{-3}$. Heterotrophic bacteria were the most numerous at site II located near the primary clarifier $\left(903 \mathrm{CFU} \cdot \mathrm{m}^{-3}\right.$,) and the least numerous at site $\mathrm{V}$ near

Table 1. List of antibiotics used in the study

\begin{tabular}{|l|c|c|}
\hline \multicolumn{1}{|c|}{ Name of antibiotic } & Symbol of disc & Concentration of antibiotic $(\mu \mathrm{g})$ \\
\hline Benzylpenicillin & P1 & 1 unit \\
\hline Cefoxitin & FOX & 30 \\
\hline Levofloxacin & LEV5 & 5 \\
\hline Gentamicin & CN10 & 10 \\
\hline Erythromycin & E15 & 15 \\
\hline Tetracycline & TE30 & 30 \\
\hline Cloramphenicol & C30 & 30 \\
\hline Rifampicin & RA5 & 5 \\
\hline
\end{tabular}


the effluent sampling chamber $\left(25 \mathrm{CFU} \cdot \mathrm{m}^{-3}\right)$. The average concentration of mannitol-positive staphylococci ranged from $5 \mathrm{CFU} \cdot \mathrm{m}^{-3}$ to $14 \mathrm{CFU} \cdot \mathrm{m}^{-3}$ depending on the sampling site. Microbial concentrations were subject to seasonal variations: the highest number of heterotrophic bacteria was noted in summer and that of staphylococci in the summer-autumn period. Mold fungi were abundant from spring to autumn. In winter, we recorded the lowest concentrations of all groups of microorganisms (Table 3).

Antibiotic sensitivity of mannitol-positive staphylococci (measured with the use of the disc diffusion method) is shown in Figure 1 . The results indicate that more than $50 \%$ of the isolated strains were resistant to penicillin, and $20 \%$ to rifampicin. Over $90 \%$ of the strains were sensitive to tetracycline, cefoxitin, gentamycin, levofloxacin and chloramphenicol.
Table 4 presents the results of the identification of bacteria grown on Chapman medium (bright yellow zone around the colony). The isolates were initially identified as mannitol-positive staphylococci; their taxonomic affiliation was later confirmed using BIOLOG fingerprinting method. The results indicate that the bacterial population was dominated by bacteria of the genus Bacillus (64\%). Staphylococci constituted only $27 \%$ of the bacterial community.

The generic composition of airborne mold fungi is presented in Figure 2. The airborne microbial population was dominated by fungi of the genus Cladosporium, constituting $64 \%$ of the fungal population. The contribution of other genera was much lower - Fusarium (12\%), Penicillium and Alternaria (9\%), Aspergillus (8\%). Molds of the genus Aureobasidium and Acremonium had the lowest contribution, namely $2 \%$ and $1 \%$ respectively.

Table 2. The concentration of microorganisms in $1 \mathrm{~m}^{3}$ of air at all sampling sites

\begin{tabular}{|c|c|c|c|}
\hline \multirow{2}{*}{ Sampling sites } & Heterotrophic bacteria & Staphylococci & Mold fungi \\
\hline & \multicolumn{3}{|c|}{$\mathrm{M} \pm \mathrm{SD}$, range $\left(\mathrm{CFU} \cdot \mathrm{m}^{-3}\right)$} \\
\hline \multirow{2}{*}{ I- near the bar screen } & $157 \pm 93$ & $14 \pm 13$ & $1858 \pm 2009$ \\
\hline & $(27-240)$ & $(0-27)$ & $(420-4830)$ \\
\hline \multirow{2}{*}{ II - near the primary clarifier } & $903 \pm 780$ & $10 \pm 10$ & $2266 \pm 1848$ \\
\hline & $(280-1680)$ & $(0-20)$ & $(210-4410)$ \\
\hline \multirow{2}{*}{ III - between the aeration tanks and bioreactors } & $112 \pm 81$ & $6 \pm 6$ & $1993 \pm 1470$ \\
\hline & $(30-200)$ & $(0-13)$ & $(160-3530)$ \\
\hline \multirow{2}{*}{ IV - near the final clarifier } & $288 \pm 482$ & $7 \pm 8$ & $7672 \pm 6509$ \\
\hline & $(27-1010)$ & $(0-17)$ & $(210-15090)$ \\
\hline \multirow{2}{*}{$V$ - near the effluent sampling chamber } & $25 \pm 17$ & $5 \pm 6$ & $2273 \pm 1458$ \\
\hline & $(17-50)$ & $(0-13)$ & $(150-3430)$ \\
\hline \multirow{2}{*}{$\mathrm{VI}$ - near the entrance to the plant } & $113 \pm 67$ & $8 \pm 11$ & $2860 \pm 2012$ \\
\hline & $(30-180)$ & $(0-27)$ & $(160-4980)$ \\
\hline
\end{tabular}

M - mean, SD - standard deviation

Table 3. The concentration of microorganisms in $1 \mathrm{~m}^{3}$ of air on the premises of the sewage treatment plant depending on the season

\begin{tabular}{|c|c|c|c|}
\hline \multirow{2}{*}{ Date of sampling } & Heterotrophic bacteria & Staphylococci & Mold fungi \\
\cline { 2 - 4 } & \multicolumn{2}{|c|}{ M \pm SD, range $\left(\mathrm{CFU} \cdot \mathrm{m}^{-3}\right)$} \\
\hline 13.05 .2014 & $275 \pm 539$ & $3 \pm 3$ & $4207 \pm 5400$ \\
\hline 24.07 .2014 & $(17-1370)$ & $(0-7)$ & $(1200-15090)$ \\
\hline 30.09 .2014 & $553 \pm 651$ & $16 \pm 6$ & $3854 \pm 3374$ \\
\hline & $(50-1680)$ & $(10-23)$ & $(980-10558)$ \\
\hline 19.01 .2015 & $(17-280)$ & $14 \pm 9$ & $4335 \pm 690$ \\
\hline & $93 \pm 104$ & $(3-27)$ & $218 \pm 102$ \\
\hline & $(17-280)$ & 0 & $(150-420)$ \\
\hline
\end{tabular}

M - mean, SD - standard deviation 
Statistical analysis shows no significant differences between the numbers of the studied microbial groups and sampling sites. Statistically significant differences were found only between the concentrations of selected groups of microorganisms in some seasons (Table 5).

\section{Discussion}

Nowadays, sewage treatment plants ensure the safety of effluents and their compliance with environmental protection in accordance with the Regulation of the Minister of the Environment of 18 November 2014, Journal of Laws 2014, item 1800. On the other hand, they can be a source of bioaerosols.

Sewage aeration and mixing (particularly the resulting splash) create favorable conditions for bioaerosol formation. Bioaerosol is generated from the bursting bubbles produced by the aeration systems which provide oxygen for biodegradation processes (Víťezová et al. 2012).
Bioaerosol formed in the process of sewage treatment may pose a potential health hazard to employees of sewage treatment plants and to inhabitants of surrounding areas.

The risks of exposure can be reduced by locating sewage treatment plants outside urban centers. However, the growth of urban sprawl brought residential and commercial development near these facilities. Recent legislative changes have forced water and sewerage companies to take measures to reduce bioaerosol emission, improve odour control, and monitor air quality on plant premises and in their vicinity (Kołwzan et al. 2012). Currently in Poland there are no relevant legal instruments defining acceptable levels of microbial air contamination. Previous standards PN-89/Z-04111/02, PN-89/Z-04111/0, annulled in 2015, have not yet been replaced. As a result, air quality assessment is based on the limit values of microbial contamination defined in the old documents. Alternatively, the results are compared with the guidelines from researchers and institutions studying this issue (Chmiel et al. 2015).

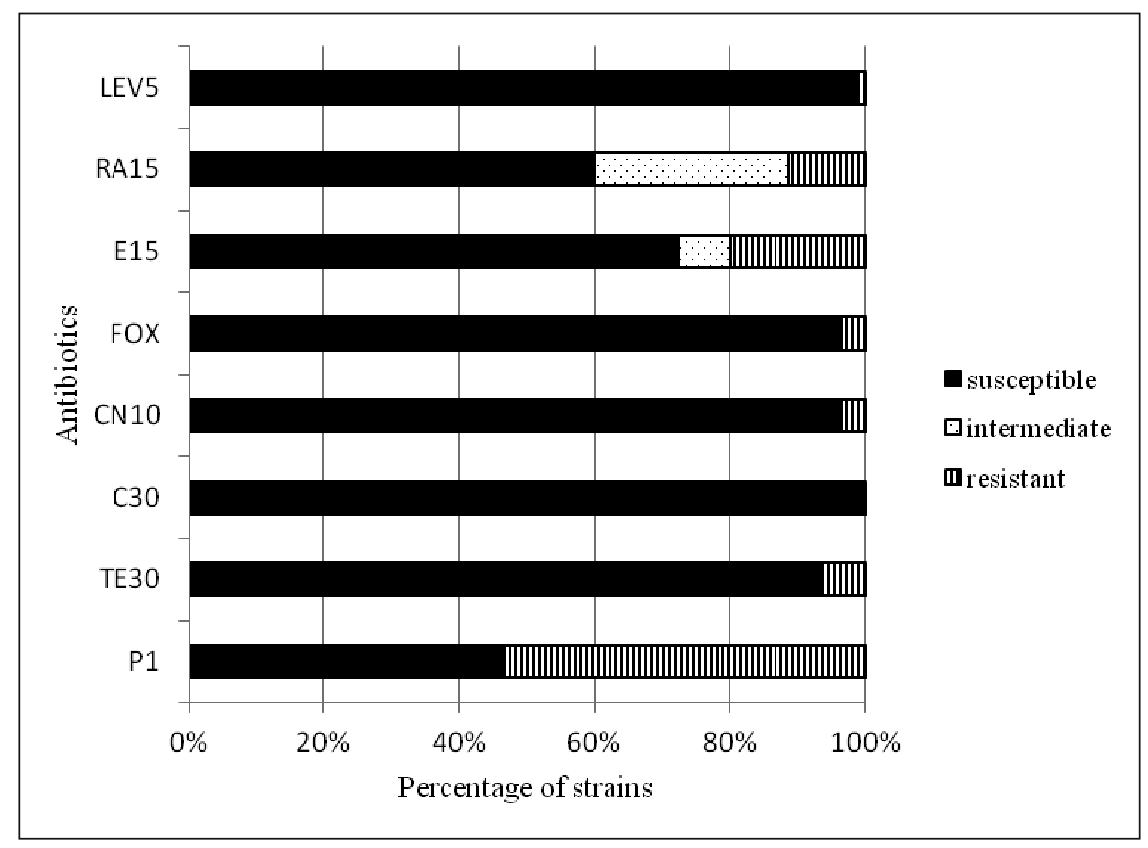

Fig. 1. Antimicrobial resistance of mannitol-positive staphylococci

P1 - Benzylpenicillin, TE30 - Tetracycline, C30 - Cloramphenicol , CN10 - Gentamicin, FOX - Cefoxitin, E15 - Erythromycin, RA5 - Rifampicin, LEV5 - Levofloxacin

Table 4. Predominant bacteria isolated from Chapman medium

\begin{tabular}{|l|c|l|}
\hline \multicolumn{1}{|c|}{ Genus } & Percentage (\%) & \multicolumn{1}{c|}{ Dominant species } \\
\hline Bacillus & 64 & B. pumilus, B. licheniformis \\
\hline & & B.ruris \\
\hline Staphylococcus & 27 & S. warneri, S. vitulinus \\
\hline & & S. epidermidis, S. hominis \\
\hline & & S. haemolyticus \\
\hline Macrococcus & 3 & M. equipercicus \\
\hline Paenibacillus & 2 & P. anaericanus \\
\hline Virgibacillus & 1 & V. proomii \\
\hline others & 3 & \\
\hline
\end{tabular}


The time of year as well as meteorological and environmental factors play an important role in the release and distribution of particulate matter and microorganisms in the air (Haas et al. 2013). The concentration of microorganisms in the air samples collected from the investigated sewage treatment plant varied and depended on the season, weather, and sampling site.

The highest average concentration of heterotrophic bacteria, i.e. $903 \mathrm{CFU} \cdot \mathrm{m}^{-3}$, was recorded at Site II near the primary clarifier. Increased average number of heterotrophic bacteria in the air is typically recorded at locations connected with pre- and primary sewage treatment, i.e. at bar screens, grit chambers and primary clarifiers. This observation is confirmed by the results obtained by $\mathrm{Li}$ et al. (2011) and Breza-Boruta (2010), who noted the highest concentration of mesophilic bacteria near grit chambers. In addition, our results indicate that lower number of heterotrophic bacteria was emitted in each subsequent stage of sewage treatment. Thus at site V located at the effluent sampling chamber we recorded their lowest average concentration, i.e. $25 \mathrm{CFU} \cdot \mathrm{m}^{-3}$. This fact is extremely important not only for the evaluation of the plant's capacity, but also for the assessment of the efficiency of methods applied in the process of sewage treatment.
The comparison of the results of this study with the literature data leads to the conclusion that the air in the investigated sewage treatment plant did not contain high number of heterotrophic bacteria. Much higher levels of bacterial contamination were recorded in the sewage treatment plant in Tehran (Iran), with a maximum number of mesophilic bacteria recorded near the aerobic digester, and a minimum, near the grit chamber (Kermani et al. 2016). Similarly, Kalwasińska et al. (2014) and Miaśkiewicz-Pęska et al. (2015) recorded considerably higher concentration of airborne heterotrophic bacteria at landfill sites.

Mannitol-positive staphylococci constituted a small group in the airborne microflora at the investigated sewage treatment plant. The highest average concentration of these microorganisms was noted at Site I located near the grit chamber, i.e. $14 \mathrm{CFU} \cdot \mathrm{m}^{-3}$. Similar results were obtained by Breza-Boruta (2010), who recorded the highest level of air contamination with these microorganisms in preliminary stages of sewage treatment in the sewage treatment plant "Igła" in Chojnice $\left(12 \mathrm{CFU} \cdot \mathrm{m}^{-3}\right)$ Much higher concentration (up to 4875 $\mathrm{CFU} \cdot \mathrm{m}^{-3}$ ) was detected at active landfill sites (Breza-Boruta 2016).

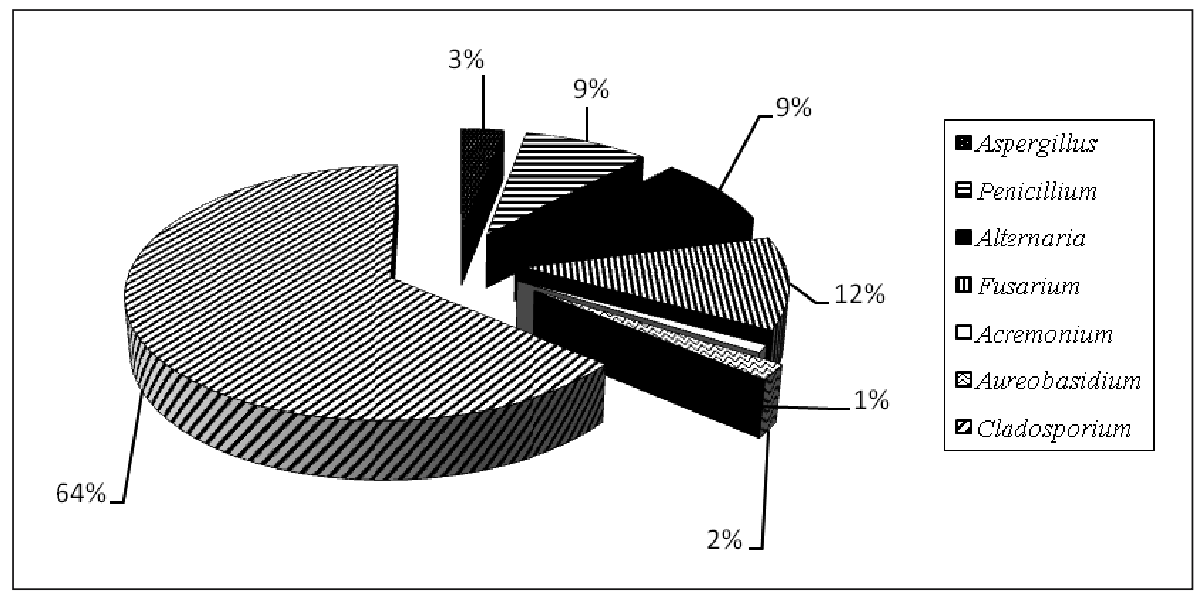

Fig. 2. Predominant genera of airborne fungi at the sewage treatment plant in Bydgoszcz

Table 5. Statistical differences between the numbers of identified groups of microorganisms in different research seasons

\begin{tabular}{|c|c|c|c|c|c|}
\hline Microorganisms & & 13.05 .2014 & 24.07.2014 & 30.09 .2014 & 19.01.2015 \\
\hline & 13.05 .2014 & & ns & ns & ns \\
\hline \multirow[t]{4}{*}{ Heterotrophic bacteria } & 24.07.2014 & ns & & ns & ns \\
\hline & 30.09 .2014 & ns & ns & & ns \\
\hline & 19.01 .2015 & ns & ns & ns & \\
\hline & 13.05 .2014 & & ns & ns & ns \\
\hline \multirow[t]{4}{*}{ Staphylococci } & 24.07 .2014 & ns & & ns & $* *$ \\
\hline & 30.09 .2014 & ns & ns & & ** \\
\hline & 19.01 .2015 & ns & ** & ** & \\
\hline & 13.05 .2014 & & $\mathrm{~ns}$ & ns & ns \\
\hline \multirow[t]{3}{*}{ Mold fungi } & 24.07.2014 & ns & & ns & ns \\
\hline & 30.09 .2014 & ns & ns & & $* * *$ \\
\hline & 19.01 .2015 & ns & ns & $* * *$ & \\
\hline
\end{tabular}

ns - differences statistically non-significant, ${ }^{*}-p \leq 0,05,{ }^{* *}-p \leq 0,01,{ }^{* * *}-p \leq 0,001$ 
Staphylococci serve as biological indicators of air pollution: they indicate the presence of pathogenic microorganisms displaying high drug resistance. The recommendation to monitor air quality is aimed at assessing the ability of pathogenic bacteria to acquire resistance to antibiotics and prevent epidemics.

Antimicrobial resistance occurs naturally over time, usually through genetic changes. However, the misuse and overuse of antimicrobials may accelerate this process. Antibiotics are often given without professional oversight and are taken by people with viral infections. As a result, antimicrobial resistance of bacterial strains can develop further, making them insensitive even to modern drugs (Nahaei et al. 2015).

In the present study, more than $50 \%$ of manniotol-positive staphylococci showed resistance to penicillin, which resulted from their ability to produce penicillinase. Similar results were obtained by Gandara et al. (2006) investigating antibiotic resistance of Staphylococcus aureus isolated from residential houses in Texas (USA): $60.46 \%$ of the tested strains were penicillin-resistant. Moreover the studies by Siviri et al. (2016) indicated too, that the most of identified isolates were resistance to penicillin $(\mathrm{n}=11)$

Different observations were made by Zhou and Wang (2013) who analyzed the effect of various antibiotics on staphylococci isolated from the waiting room in the metro station in Shanghai; only $28 \%$ of the strains were resistant to penicillin. According to the literature data bacteria isolated from places different than hospitals are sensitive to majority of currently used antibiotics and resistant only to methacycline and tetracycline (Hrynkiewicz et al. 2005). Our results show that the air in the sewage treatment plant in Bydgoszcz did not contain multidrug-resistant staphylococci. More than $90 \%$ of the analyzed strains were sensitive to tetracycline, cefoxitin, gentamycin, chloramphenicol, and levofloxacin. Similarly, Breza-Boruta and Paluszak (2007) did not detect the presence of staphylococci resistant to multiple antibiotics in the Sewage Treatment Plant in Torun.

The population of microorganisms at sewage treatment plants and landfill sites contains a diversity of species including those which are dangerous to human health. Airborne bacteria at the investigated sewage treatment plant were dominated by bacteria of the genus Bacillus (64\%). Stapylococci constituted only $27 \%$ of the bacterial population. Similar results were obtained by Kermani et al. (2016) investigating air quality at the sewage treatment plant in Tehran, Iran. They reported similar percentage contribution of the following three genera: Bacillus spp. (36\%), Staphylococcus spp. (35\%) and Micrococcus spp. (29\%). Kalwasińska et al. (2014) also noted the dominance of Bacillus spp. (45.5\%) and Staphylococcus spp. (30.6\%) among mesophilic bacteria in the air at the landfill site in Toruń. In this study we identified five Staphylococcus spp.: S. warneri, S. vitulinus, S. epidermidis, S. hominis, and S. haemolyticus. Frączek and Kozdrój (2016) noted the presence of S. sciurii i S. xylosus at the landfill site in Barycz.

We noted seasonal differences in the abundances of airborne microorganisms; heterotrophic bacteria and mannitolpositive staphylococci were the most numerous in summer, and mold fungi, in autumn. In winter, the concentrations of all microorganisms decreased sharply, which can be attributed to the unfavorable weather conditions, e.g. low temperature reducing the survival rate of microorganisms. Similar results were published by other researchers investigating air quality at sanitation facilities (Kołwzan et al. 2012, Miaśkiewicz-Pęska and Szyłak-Szydłowski 2015, Schlosser et al. 2016).

Fungi are a predominant group in the air and they account for about $70 \%$ of all microorganisms. More than 40,000 species of fungi have been isolated so far (Abdel Hameed et al. 2015).

Mold fungi were the most abundant group of microorganisms also at the studied sewage treatment plan. Their highest number was recorded at Site IV near the final clarifier $\left(7672 \mathrm{CFU} \mathrm{m}^{-3}\right)$, the lowest, at Site I near the bar screen $\left(1858 \mathrm{CFU} \cdot \mathrm{m}^{-3}\right)$ and at site III between aeration chambers (1993 CFU $\left.\cdot \mathrm{m}^{-3}\right)$.

According to numerous studies aeration chambers in bioreactor tanks are a major source of microbial emission. In our study, however, concentration of microorganisms at the sampling site situated between the aeration chambers was low or lower than at other sites. Budzińska et al. (2011) suggest that aeration equipment and methods (coarse or fine bubble aeration) determine microbial emission in sewage treatment. Coarse bubble aeration is generally associated with the highest emission of microorganisms (Brandi, 2000), while fine bubble aeration, with the lowest. Bydgoszcz facility uses ECOQUARTZ 60 ceramic tubes for fine bubble aeration. Consequently, microbial emission investigated in this study was lower than in other studies.

Environmental pollution and threats connected with the presence of fungi in the air results from the fact that they can cause allergies, asthma, broncho- and pulmonary mycoses, and general infections (Kim et al., 2013, Kalwasińska et al., 2014).

The airborne fungi at the sewage treatment plant in Bydgoszcz were dominated by the genus Cladosporium (64\%). The contribution of other genera was much lower, namely Fusarium (12\%), Alternaria and Penicillium (9\%) and Aspergillus (8\%). Aureobasidium and Acremonium were the least numerous, and accounted for only $2 \%$ and $1 \%$ of fungal population, respectively. Similar compositions were recorded by other researchers at landfills (Kalwasińska et al. 2014, Breza-Boruta 2016) or sewage treatment plants (Viegas 2014, Kermani et al. 2016).

Numerous publications and our own studies indicate that sewage treatment plants are a source of bioaerosol, which may contain pathogenic microorganisms, posing health hazard for both employees of these facilities and inhabitants of the surrounding areas. Therefore, there is a need for regular monitoring of air quality on the premises and in vicinity of these plants. The results indicating microbial air contamination should suggest taking appropriate protection measures. The results of numerous studies indicate that the impact of sewage treatment plants on the environment could be reduced by undertaking certain remedial actions such as hermetisation of the facilities which are the biggest emitters of aerosol or planting vegetation barriers. Other recommended actions include the location of sewage treatment plants on the leeward side of cities and at a certain distance from residential areas (Michałkiewicz et al. 2009).

\section{Conclusions}

The air on the premises of the sewage treatment plant in Bydgoszcz, Poland was dominated by mold fungi. In relation to the literature data, the concentration of heterotrophic bacteria was low. 
Low emission of mold fungi at the site located near the aeration chamber can be associated with fine bubble aeration in sewage treatment.

The highest air contamination with all studied groups of microorganisms was recorded at locations where mechanical sewage treatment is performed. During the subsequent stages lower numbers of heterotrophic bacteria were emitted into the air.

The results of many studies indicate that it is necessary to monitor air quality in sewage treatment plants. Hermetization of facilities on their premises which are the biggest pollutants can help reduce the emission of bioaerosol.

The air in the investigated sewage treatment plant did not contain multidrug-resistant staphylococci.

\section{References}

Abdel Hameed, A.A., Habeebuallah, T., Mashat, B., Elgendy, S., Elmorsy, T.H. \& Elserougy, S. (2015). Airborne fungal pollution at waste application facilities, Aerobiologia, 31 (3), pp. 283-293.

Barberan, A., Dunn, R.R., Reich, B.J., Pacifici, K., Laber, E.B., Menninger, H.L., Morton, J.M., Henley, J.B., Leff, J.W., Miller, S.L. \& Fierer, N. (2015). The ecology of microscopic life in household dust, Proceedings of the Royal Society B: Biological Sciences, 282.

Breza-Boruta, B. (2016). The assessment of airborne bacterial and fungal contamination emitted by a municipal landfill site in Northern Poland, Atmospheric Pollution Research, pp. 1-10. http://dx.doi.org/10.1016/j.apr.2016.06.011

Breza-Boruta, B. (2010). An assessment of microbiological air pollution at the sewage treatment plant, Woda - Srodowisko - Obszary Wiejskie, 10, pp. 49-57. (in Polish)

Breza-Boruta, B. \& Paluszak, Z. (2007). The distribution of antibiotic-resistant staphylococci in the air at the sewage treatment plant, Medycyna Weterynaryjna, 63, pp. 717-720. (in Polish)

Budzińska, K., Jurek, A., Szejniuk, B., Michalska, M. \& Wroński, G. (2011). Microbial air contamination at the municipal sewage treatment plant, Rocznik Ochrona Środowiska, 13, pp. 1543-1558. (in Polish)

Brandi, G., Sisti, M. \& Amagliani, G. (2000). Evaluation of the environmental impact of microbial aerosols generated by wastewater treatment plants utilizing different aeration systems, Journal of Applied Microbiology, 88, pp. 845-852.

Chmiel, M.J., Frączek, K. \& Grzyb, J. (2015). The problems of monitoring microbiological air contamination, Woda-Środowisko - Obszary Wiejskie, 1(49), pp. 17-27. (in Polish)

EUCAST - European Committee on Antimicrobial Susceptibility Testing (2015). Breakpoints tables for interpretation of MICs and zones diameters. Version 5.0, 2015. (http://www.eucast.org(21.08.2017)).

Frączek, K. \& Kozdrój, J. (2016). Strain differentation of airbone opportunistic microorganisms within a municipal landfill area as assessed by PCR MP method, Aerobiologia, 32, pp. 499-511.

Filipkowska, Z., Michalak, A., Pawlas, K., Janczukowicz, W., Krzemieniewski, M. \& Pesta, J. (2009). Municipal wastewater treatment plant with activated sludge tanks aerated by CELPOX devices as a source of Microbiological pollution of the atmosphere, Polish Journal of Environmental Studies, 11(6), pp. 639-648.

Gandara, A., Mota, L.C., Flores, C., Perez, H.R., Green, C.F. \& Gibbs, S.G. (2006). Isolation of Staphylococcus aureus and antibiotic-resistant Staphylococcus aureus from residential indoor bioaerosols, Environmental Health Perspectives, 114(12), pp. 1859-1864.

Haas, D., Galler, H., Luxner, J., Zarfel, G., Buzina, W., Friedl, H., Marth, E., Habib, J. \& Reinthaler, F.F. (2013). The concentrations of culturable microorganisms in relation to particulate matter in urban air, Atmospheric Environment, 65, pp. 215-222.
Hrynkiewicz, W., Sulikowska, A., Szczypa, K., Gniadowski, M. \& Skoczyńska, A. (2005). Recommendations for microbial sensitivity tests used to determine bacterial susceptibility to antibiotics and chemotherapeutics, Postępy Mikrobiologii, 44, pp. 175-192. (in Polish)

Kalwasińska, A., Burkowska, A. \& Swiontek-Brzezinska, M. (2014). Exposure of workers of muncipal landfill site to bacterial and fungal aerosol, Clean-Soil, Air, Water, 42 (10), pp. 1337-1343.

Kermani, M., Dehghani, A., Farzadkia, M., Asl, F.B. \& Zeinalzadeh, D. (2016). Assessment of bioaerosol contamination in an urban wastewater treatment plant in Tehran, Iran, Journal of Air Pollution and Health, 1 (3), pp. 161-170.

Kim, K.H., Jahan, S.A. \& Kabir, E. (2013). A review on human health perspective of air pollution with respect to allergies and asthma, Environment International, 59, pp. 41-52.

Kołwzan, B., Adamiak, W., Grabas, K. \& Pawełczyk, A. (2005). Basic microbiology in environmental protection, Oficyna Wydawnicza Politechniki Wrocławskiej, Wrocław 2005. (in Polish)

Kołwzan, B., Jadczyk, P., Pasternak, G., Głuszczak, J., Pawlik, M., Krawczyńska, M., Klein, J. \& Rybak, J. (2012). Assessing air quality in the proximity of muncipal sewage treatment plant: a case study, Ochrona Środowiska, 34 (2), pp. 9-14. (in Polish)

Li, L., Gao, M. \& Liu, J. (2011). Distribution characterization of microbial aerosols emitted from a wastewater treatment plant using the Orbal oxidation ditch process, Process Biochemistry, 46 (4), pp. 910-915.

Łebkowska, M. (2001). Zanieczyszczenia mikrobiologiczne w powietrzu obiektów komunalnych i przemysłowych, Inżynieria i Ochrona Środowiska, 4 pp. 3-4. (in Polish)

Miaśkiewicz-Pęska, E. \& Szyłak-Szydłowski, M. (2015). Air pollution in landfill of wastes other than hazardous or inert, Archives of Environmental Protection, 2, pp. 41-46.

Michalak, A. \& Pawlas, K. (2012). Influence of biological aerosol from wastewater treatment plants on workers and the local residents health - literature review, Medycyna Środowiskowa, 15(4), pp. 116-122. (in Polish)

Michałkiewicz, M. (2015). Microbiological pollution in the areas of sewage treatment plant, Part. 2, Technologia wody, 4, pp. 44-52.

Michałkiewicz, M., Pruss, A., Dymaczewski, Z., Jeż-Walkowiak, J. \& Kwaśna, S. (2011). Microbiological air monitoring around municipal wastewater treatment plants, Polish Journal of Environmental Studies, 20, pp. 1243-1250.

Michałkiewicz, M., Pruss, A., Dymaczewski, Z. \& Michalak, J. (2009). Impact of the containment of selected stages of sewage treatment on microbial pollution. Polish Environmental Engineering five years after Poland joined the European Union. Monographs, Komitet Inżynierii Środowiska, PAN Lublin, 2(59), pp. 135-143.

Nahaei, M.R., Shahmohammadi, M.R., Ebrahimi, S. \& Milani, M. (2015). Detection of Methicillin-Resistant Coagulase-Negative Staphylococci and Surveillance of Antibacterial Resistance in a Multi-Center Study from Iran, Jundishapur Journal of Microbiology, 8(8) e: 19945.

Samson, R.A. \& Hoekstra, E.S. (2000). Introduction to food- and airborne fungi. Published and distributed by Centraalbureau voor Schimmelcultures, P.O.Box 85167, 3508 AD Utrecht, The Netherlands.

Schlosser, O., Robert, S. \& Debeaupuis, C. (2016). Aspergillus fumigatus and mesophilic moulds in air in the surrounding environment downwind of non-hazardous waste landfill sites, International Journal of Hygiene and Environmental Health, 219, pp. 239-251.

Sivri, N., Bağcigil, A.F., Metiner, K., Şeker, D.Z., Orak, S., Durak, S.G. \& Sönmez, V.Z. (2016). Curturable airbone bacteria and isolation of methicillin-resistant coagulase-negative staphylococci from outdoor environments on European side of Istanbul, Turkey, Archives of Environmental Protection, 3, pp. 77-86. 
Viegas, C., Faria, T., Quintal Gomes, A., Sabino, R., Seco, A. \& Viegas, S. (2014). Fungal contamination in two Portuguese wastewater treatment plants, Journal of Toxicology and Environmental Health, Par A, 77, pp. 77-90.

Vítězová, M., Vítěz, T., Mlejnková, H. \& Lošák, T. (2012). Microbial contamination of the air at the wastewater treatment plant,
Acta Universitatis Agriculturae et Silviculturae Mendelianae Brunensis, 3, pp. 233-240.

Zhou, F. \& Wang, Y. (2013). Characteristics of antibiotic resistance of airborne Staphylococcus isolated from metro stations, International Journal of Environmental Research and Public Health, 10 (6), pp. 2412-2426.

\title{
Mikrobiologiczne zanieczyszczenie powietrza na terenie oczyszczalni ścieków oraz antybiotykooporność bakterii z rodzaju Staphylococcus spp.
}

\begin{abstract}
Streszczenie: Celem pracy była ocena stopnia mikrobiologicznego zanieczyszczenia powietrza na terenie oczyszczalni ścieków, określonego na podstawie liczebności wybranych grup drobnoustrojów oraz ocena wrażliwości wyizolowanych szczepów gronkowców na wybrane antybiotyki, co pozwoliło określić stopień ich antybiotykooporności. Badania przeprowadzono w cyklu sezonowym, przy użyciu metody zderzeniowej za pomocą próbnika MAS-100 Merck. Próbki pobierane były z 6 stanowisk badawczych zlokalizowanych w miejscach reprezentujących poszczególne etapy oczyszczania ścieków. Lekowrażliwość wyizolowanych gronkowców oceniano metodą dyfuzyjno-krążkową zgodnie z rekomendacjami EUCAST. Analizy wykazały, że wśród mikrobiota powietrza najliczniej występowały grzyby pleśniowe osiągając maksimum liczebności na stanowisku IV zlokalizowanym przy osadniku wtórnym radialnym $\left(7672 \mathrm{CFU} \cdot \mathrm{m}^{-3}\right)$. Bakterie heterotroficzne i gronkowce mannitolododatnie najliczniej występowały w miejscach wstępnego etapu oczyszczania ścieków. Wraz z zaawansowaniem procesów oczyszczania, ścieki emitowały do powietrza atmosferycznego coraz mniejszą ilość mikroorganizmów. Na podstawie antybiogramów stwierdzono, że ponad 50\% badanych szczepów Staphylococcus spp. wykazywała oporność wobec penicyliny i $20 \%$ wobec rifampicyny, natomiast $90 \%$ analizowanych szczepów było wrażliwych na pozostałe antybiotyki. Wśród grzybów pleśniowych w powietrzu na terenie oczyszczalni ścieków odnotowano grzyby z rodzaju: Cladosporium, Fusarium, Alternaria, Penicillium, Aspergillus, Aureobasidium i Acremonium.

Największym zanieczyszczeniem powietrza, w przypadku wszystkich badanych grup mikroorganizmów, charakteryzowały się stanowiska zlokalizowane w miejscach odpowiedzialnych za część mechaniczną procesu oczyszczania ścieków. Wraz z zaawansowaniem procesów oczyszczania, ścieki emitowały do powietrza atmosferycznego coraz mniejszą ilość bakterii heterotroficznych. Na terenie oczyszczalni ścieków nie stwierdzono rozprzestrzeniania się szczepów gronkowców wielolekoopornych.
\end{abstract}

